\title{
Water Quality Index Performance for River Pollution Control Based on Better Ecological Point of View (A Case Study in Code, Winongo, Gadjah Wong Streams)
}

\author{
Sri Puji Saraswati ${ }^{1 *}$, Mochammad Venly Ardion ${ }^{1}$, Yul Hendro Widodo ${ }^{1}$, Suwarno Hadisusanto ${ }^{2}$ \\ 'Department of Civil and Environmental Engineering, Universitas Gadjah Mada, Yogyakarta, INDONESIA \\ ${ }^{2}$ Faculty of Biology, Universitas Gadjah Mada, Yogyakarta, INDONESIA \\ *Corresponding authors: spswatinz@ugm.ac.id
}

SUBMITTED 21 November 2018 REVISED 3 December 2018 ACCEPTED 14 January 2019

\begin{abstract}
The quality of river water quality monitoring data sometimes can be inaccurate. Evaluation of the effectiveness of water pollution control programs needs good quality data to calculate the Water Quality Index (WQI) with the aim to meet the requirement to protect biodiversity and maintain various water functions. Thirty-five water quality variables from Code, Gadjah Wong, and Winongo rivers were taken as data, conducted by Environmental Agency of Yogyakarta in 2004 - 2015. There were only 19 out of 35 water quality variables having good data after improvement of monitoring data, transformation/standardization and analysis of the significant water quality variables with PCA (Principle Component Analysis) and Factor Analysis (FA). WQIs formula in the three rivers used the same 5 significant variables i.e. EC, DO, COD, NH3N, Total Coliform, and "weighted sum index" as the sub-index aggregation technique, with different sub-index coefficients. Winongo River had the best water quality and Gajah Wong River was the worst. According to the relationship of river water discharge and WQIs index, large discharge during rainy seasons does not always decrease the level of pollution, but it tends to increase the WQIs. More effective ways to improve the stream water quality during dry seasons should further be investigated.
\end{abstract}

KEYWORDS Water quality index; water quality standard; water pollution; PCA; FA

(c) The Author(s) 2018. This article is distributed under a Creative Commons Attribution-ShareAlike 4.0 International license

\section{INTRODUCTION}

Spatial and temporal water quality monitoring in a broad ecoregional need to consider the efficient and effective number of water quality variables for its water quality index (WQI) and able to detect water quality changes that deviate from the ecological water quality standard (Karr, 1991). The more water quality variables monitored each year, the more costs will be incurred in water quality monitoring. Without quality assurance, the monitoring results` of water quality data analysis and its conclusions can be false. Consequently, there will be lost of repair cost, which is not a major problem, in the other side, the environmental disasters which may occur because of the main problem in the water pollution control program cannot be detected (Berthouex \& Brown, 2002). The water quality needs to be monitored, not only on the targeted rivers for pollution control programs. It is also important to continuously monitor the unpolluted rivers as they have benefit to Initial Environmental Setting and to the development of water quality conservation measures that support better ecological conditions.

This research aims to evaluate the standard of water quality monitoring data, to find the significant variables of river water quality at Code River, Gadjah Wong River, and Winongo River, which is located in one sub-district area of Opak-Oyo in Yogyakarta. The river ecological Water Quality Index (WQIs) was then compiled and assessed its relationship to the river flows and was used to evaluate the effectiveness of river pollution control programs in order to achieve eco-oriented river pollution control.

\section{DATA SET AND METHODS}

This research used water quality monitoring data from the Environmental Agency (BLH) of Yogyakarta in 2004 - 2015, with 35 parameters of water quality including discharge data at the same time in 8 of 9 monitoring points of the Code River, at 8 of 10 
monitoring points of Gadjah Wong River, in 8 of 10 monitoring points of the Winongo River (Figure 1).

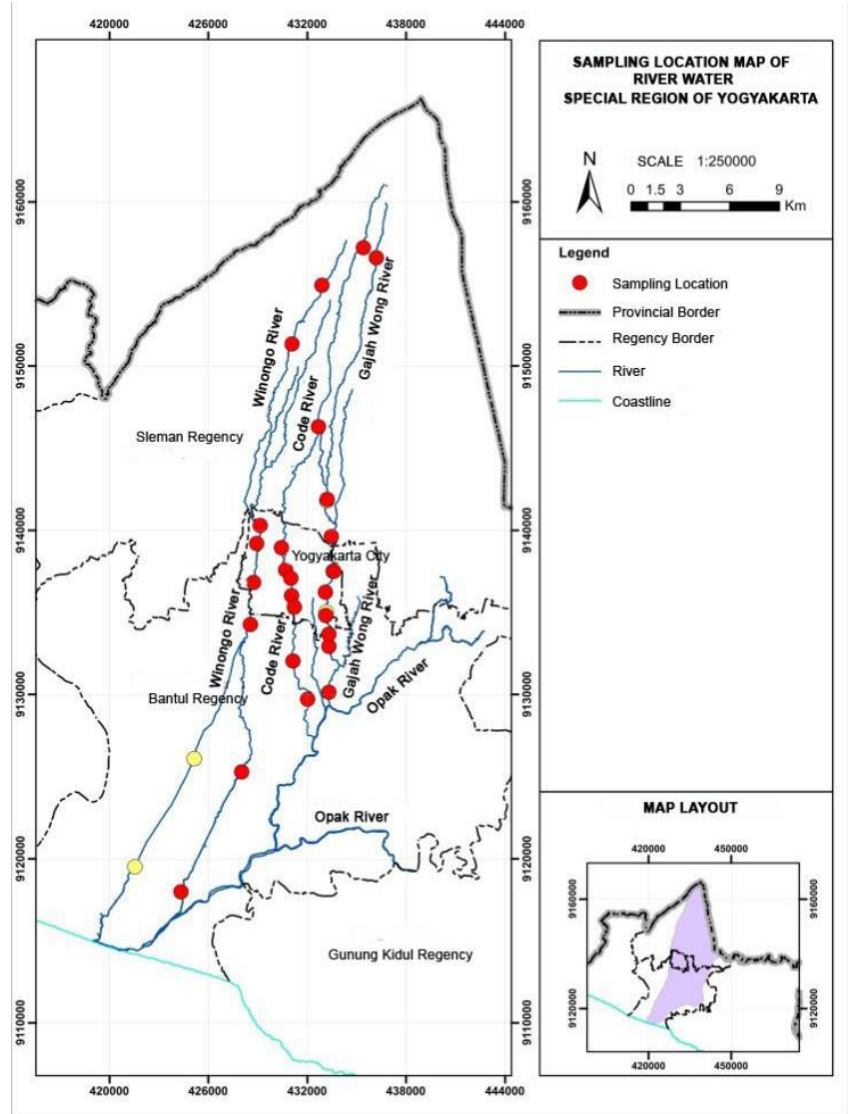

Figure 1. Water quality monitoring point (red dot) in Code, Gadjah Wong, and Winongo Rivers, Yogyakarta

Significant water quality variables were derived from data management, data recovery, transformation/ standardization with eco-hydraulic based water quality standards (Saraswati, 2015), multivariate PCA (Principle Component Analysis) analysis and Factor Analysis (Putranda \& Saraswati, 2016). Ecohydraulic background condition was based on a water-quality conservation philosophy, where the water quality variables of the river needed to be comprehensively reviewed by incorporating biodiversity life-protection criteria into the water quality background condition indicators of physical-bacteriological-chemistry.

\subsection{Water Quality Data \& Data Quality}

The data of river water quality might not good because there were sensors and limitations by the detection instrument, missing value, and outlier data, where data was deviated from data trends because of the incident or natural disaster (Berthouex and Brown, 2002). The data quality was improved in several ways, i.e. selection of data based on a) the method of correlation from the monitoring sites, b) monitoring duration, c) the relationship of water quality parameters, e.g.TDS, and EC, Ammonia-NitriteNitrate, Total Coliform - Escherichia Coli, BOD5-COD, and d) interpolation method, which was then being analyzed with univariate and multivariate evaluation and used for further data analysis.

\subsection{Water Quality Conservation Targets and Water Quality Standard Regulation}

Abbasi and Sarkar (2006) stated that water quality standards in the water quality index were varied depends on the target. The quality standard of river water is a site-specific background condition, where water has its various functions as drinking water, agriculture, fisheries, industry, and others (Dudgeon, 1999). Control of water pollution in water resources should be targeted as ethical environmental water quality conservation (Vitalisme).

\subsection{Transformation and Standardization}

The transformation/standardization of Water Quality Conservation/WQC (Saraswati, 2015) produces different PCA ordination with the standardization value of average $=0$ and variance $=1$. If the standardization of average 0 and variance 1 makes all variables have the same data mean $(=0)$ and the same range of variance $(=1)$ and dimensionless, the transformation /standardization of WQC makes all water quality variables dimensionless and have a range of values between -1 to +1 , where the value 0 is a water quality variable that has a concentration equal to the water quality standard or background condition of water quality conservation. The WQC transformation method has integrated the use of water quality background condition into a commonly used transformation /standardization method with multivariate analysis. The transformation/ standardization of WQC has 4 kinds of water quality variables, i.e.:

a) If the value of water quality variable concentration decreases, then the level of pollution increases, (e.g. DO water quality variable), data transformation,

$$
y_{i}=\frac{x_{i}-\operatorname{Stan}_{i}}{c_{i}}
$$

b) If the value of water quality variable concentration increases, then the level of pollution increases (e.g. BOD5, COD and the other water quality variables),

$$
y_{i}=\frac{\operatorname{Stan}_{i}-x_{i}}{c_{i}}
$$


where $y_{i}$ is transformation result value of water quality variable $i, x_{i}$ is the concentration value (raw value) of variable water quality $i, \operatorname{Stan}_{i}$ is quality standards of water quality variables $i, c_{i}$ is a maximum range, theoretical concentration on standard quality (maximum theoretical concentration - Stan) variable $i$.

c) If the default value of "Stani" has a range (e.g. pH water quality variable)

$$
\begin{aligned}
& \text { for } x_{i}<\operatorname{Stan}_{i, \text { average }}: y_{i}=\frac{x_{i}-\operatorname{Stan}_{i, \text { min }}}{c_{i}} \\
& \text { for } x_{i}>\operatorname{Stan}_{i \text {,average }}: y_{i}=\frac{\operatorname{Stan}_{i, \max }-x_{i}}{c_{i}}
\end{aligned}
$$

where $y_{i}$ is transformation result value of water quality variable $i, x_{i}$ is the concentration value (raw value) of water quality variable $i, \operatorname{Stan}_{i}$ is quality standards of water quality variables $i$, Stan $_{i, \text { average }}=$ (maximum value of quality standard + minimum value of quality standard) $/ 2, \operatorname{Stan}_{i, \max }=$ maximum value of standard quality range, water quality variable $i, \operatorname{Stan}_{i, \min }=$ minimum value of standard quality range, water quality variable $i, c_{i}$ is $\operatorname{Stan}_{i}$, average.

The default result value of WQC shows that the value will have an interval between -1 and +1 , where,

a) the positive deviation sign (+) means good water quality, and if the deviation value is positive, it means better/less polluted water quality,

b) the negative deviation sign (-) means poor water quality, and if the deviation value is negative, it means the water quality is worse/polluted.

The WQC background condition value of the proposed river water in the ecoregional river of Code, Gadjah Wong and Winongo, and its comparison with the 1st Class Quality Standard of Government Regulation no. 82 of 2001, are presented in Table 1 columns (3) and (4). The WQC background condition values measurements and ci ranges (Table 1, column 6) are rationally adjusted based on the minimum and maximum scores of theoretical scientific studies (Table 1, column 5), that can be measured in the water area according to various reference/literature sources, ecotoxicology for aquatic biota and natural characteristics (climate/biogeochemical) in the study area, and it has been verified (Saraswati, 2017;
Saraswati, 2015). The measured water quality concentrations in the three rivers are summarized in columns (7-9).

\subsection{River Water Quality Index (WQIs)}

The WQIs in this study is a single index of empirical water quality at local ecological conditions in Indonesia, which has different climate and environment condition with the other countries. The current developed WQIs formula was differentiated based on the number and types of significant water quality parameters, specific water utilization targets, method to weigh the parameters of water quality, method of data transformation/standardization, method of sub-index aggregation, the number of water quality class, the type of water quality monitoring, determination of the number, and determination of water quality class (Lumb, et al., 2006). The steps of WQI compilation method were conducted as a selection for significant water quality variables, determination of the objectives or targets of water quality index used in the process, the transformation/ standardization in order to have a scale on the same order and dimensionless, weighing water quality variables, and composing the WQIs formula.

In this study, the WQIs development used comprehensive method with the following advantages: (Saraswati, 2015) (1) prepared with a holistic approach and may reflect interdisciplinary interests, (2) objective /minimum subjective factors, (3) easy data retrieval and consistent with the purpose of monitoring, (4) easy and need only low price to know the rivers water quality status, (5) it was an ex-situ method that can reflect the rivers in-situ conditions, (6) it can be practically used by the Managers at local and regional levels, (7) a single index for reporting water quality monitoring results which can be easily uploaded into the latest environmental information systems. The subjective factor will be minimized along with the reduction of measurable original water quality variables into the smaller quantities and type of water quality and variables of water quality without significantly reducing the characteristics of the data. The empirical WQIs formula that was obtained in this research is different from the WQI formulas in the Decree of the Minister of the Environment. No.115 of 2013 regarding Guidelines for the Establishment of Water Quality Status. 
Table 1. Water quality conservation reference at Code, Gadjah Wong, Winongo River and range of "ci"

\begin{tabular}{|c|c|c|c|c|c|c|c|c|}
\hline \multirow[b]{2}{*}{ No. } & \multirow[b]{2}{*}{ Variable } & \multirow{2}{*}{$\begin{array}{l}1^{\text {st }} \text { Class } \\
\text { Quality } \\
\text { standards }\end{array}$} & \multirow{2}{*}{$\begin{array}{l}\text { Benchmark } \\
\text { of WQC }\end{array}$} & \multirow{2}{*}{$\begin{array}{l}\text { Min \& Max } \\
\text { (Theoretical) }\end{array}$} & \multirow[b]{2}{*}{$\mathrm{C}_{\mathrm{i}}$} & \multicolumn{3}{|c|}{ Min-Max (measurable) } \\
\hline & & & & & & Max & Min & Average \\
\hline 1 & $\mathrm{pH}$ & $6-9$ & $6-9$ & $6-9$ & 7.5 & 8.9 & 5.1 & 7.175 \\
\hline 2 & TDS (mg/L) & 1,000 & 1,000 & $1 \& \geqslant 20,000$ & 19,000 & 724 & 1 & 186.543 \\
\hline 3 & TSS (mg/L) & 50 & 50 & $0.001 \& \geqslant 400$ & 350 & 907 & 2 & 239.325 \\
\hline 4 & Turbidity (NTU) & - & 5 & $0.001 \& \geqslant 50$ & - & - & - & - \\
\hline 5 & $\mathrm{EC}(\mathrm{uS} / \mathrm{cm})$ & - & 300 & $50 \& \geqslant 700$ & 400 & 966 & 103.23 & 339.16 \\
\hline 6 & $\mathrm{DO}(\mathrm{mg} / \mathrm{L})^{*}$ & 6 & 6 & $0 \& \geqslant 10$ & 6 & 10 & 1.010 & 6.017 \\
\hline 7 & $\mathrm{BOD}_{5}(\mathrm{mg} / \mathrm{L})$ & 2 & 3 & $0.5 \& \geqslant 50$ & 47 & 48 & 0.500 & 7.715 \\
\hline 8 & COD (mg/L) & 10 & 10 & $5 \& \geqslant 100$ & 90 & 288 & 3.45 & 25.41 \\
\hline 9 & $\mathrm{NO}_{2}(\mathrm{mg} / \mathrm{L})$ & 0.06 & 0.02 & $0.001 \& \geqslant 1$ & 0.98 & 1.71 & 0.001 & 0.11 \\
\hline 10 & $\mathrm{NO}_{3}(\mathrm{mg} / \mathrm{L})$ & 10 & 2 & $0.01 \& \geqslant 100$ & 98 & 8.967 & 0.0001 & 2.37 \\
\hline 11 & $\mathrm{NH}_{3} \mathrm{~N}(\mathrm{mg} / \mathrm{L})$ & 0.5 & 0.05 & $0.01 \& \geqslant 1.25$ & 1.2 & 2.72 & 0 & 1.1 \\
\hline 12 & Total P (mg/L) & 0.2 & 0.2 & $0.002 \& \geqslant 50$ & 159.8 & 4.942 & 0 & 0.34 \\
\hline 13 & Fluoride (mg/L) & 0.5 & 1.2 & $0.009 \& \geqslant 6$ & 4.80 & 2.6 & 0 & 0.52 \\
\hline 14 & $\mathrm{Cr}(\mathrm{VI})(\mathrm{mg} / \mathrm{L})$ & 0.05 & 005 & $0.001 \& \geqslant 0.25$ & 0.2 & 3 & 0 & 0.01 \\
\hline 15 & $\mathrm{H}_{2} \mathrm{~S}(\mathrm{mg} / \mathrm{L})$ & 0.002 & 0.002 & $0.001 \& \geqslant 0.3$ & 0.298 & 0.506 & 0 & 6.078 \\
\hline 16 & Detergent (mg/L) & 0.2 & 0.2 & $0.001 \& \geqslant 3.0$ & 0.280 & 1607.7 & 0 & 75.44 \\
\hline 17 & $\begin{array}{l}\text { Oil \& Grease } \\
(\mu \mathrm{g} / \mathrm{L})\end{array}$ & 1,000 & 20 & $0 \& \geqslant 20,000$ & 19,980 & 400,000 & 0 & $1,629.57$ \\
\hline 18 & $\begin{array}{l}\text { E. Coli (MPN/100 } \\
\mathrm{mL})\end{array}$ & 100 & 4,000 & $1 \& \geqslant 20,000$ & 4,000 & $24,000,000$ & 0 & $288,037.66$ \\
\hline 19 & $\begin{array}{l}\text { Total Coli } \\
\text { (MPN/100 mL) }\end{array}$ & 1,000 & 20,000 & $5 \& \geqslant 50,000$ & 20,000 & $712,000,000$ & 0 & $1,328,310.12$ \\
\hline
\end{tabular}

\section{RESULT AND DISCUSSION}

\subsection{Quality of Water Quality Monitoring Data}

Identification of outlier data, sensor, and blank data have set the terms for the amount of good data $\geqslant 70 \%$ that can be used in this research. The results were selected from 19 out of 35 water quality variables (Table 2) for the improvement process and "smoothing" data. If there were good data showed in 2 rivers but still had a bad result in the other one river, it means the data did not support, thus the "smoothing" process can be continued with the help of correlation between variables method. In the end, WQI score was calculated based on 5 significant variables because there was a strong correlation between several significant variables of water quality. The variables were EC, DO, COD, NH3N, and Total Coliform. In comparison, Liou et al. (2004) in Taiwan's Keya River has used 13 variables. River Pollution Index in Taiwan used 4 water quality variables, i.e. DO, BOD5, SS, NH3N. INWQS (Interim National Water Quality Standard) from The Department of Environmental of Malaysia used 6 variables, i.e. DO, TSS, BOD5, Total Phosphate, Turbidity, Ammonia Nitrogen (Mamun \& Idris, 2008). Kannel (2007) even only used 1 water quality variable, i.e. DO, for the pollution study on Nepal's Bagmati River.

The variable of Total Coliform showed the number of Escherichia Coli (Kenner, 1878 in Thoman and Mueller, 1987) and make a simple laboratory analysis. The water quality variables of EC detect salt compounds in river water due to human waste or mineral water ions due to the weather and climate change. Water quality variable of DO detects water freshness and its potential impact on the river biota, COD detects water contamination due to domestic and industrial organic waste, NH3N detects potential impact of river water eutrophication that was caused by industry, domestic, agriculture, and fisheries, while Total Coliform detects a potential impact on human health. Five water quality variables are expected to detect the impact of river water quality due to the activities of hotels, malls, restaurants, bakeries, car/ motorcycles wash, health services, livestock industry, printing industry, gas station, railway station, tofu/tempe industry, batik industry, chicken poultry, pharmaceutical industry, laundry, automotive industry, beauty salon (Badan Lingkungan Hidup (BLH) DIY, 2015), in the catchment area of Code, Gadjah Wong, Winongo Rivers. 
Table 2. Data quality of water quality measurement in Code, Gadjah Wong, and Winongo Rivers

\begin{tabular}{|c|c|c|c|c|c|c|c|c|c|c|c|c|}
\hline \multirow{2}{*}{ Variable } & \multicolumn{4}{|c|}{ Code River } & \multicolumn{4}{|c|}{ Gadjah Wong River } & \multicolumn{4}{|c|}{ Winongo River } \\
\hline & GQD & MD & $\mathrm{AD}$ & $\mathrm{CD}$ & GQD & MD & $\mathrm{AD}$ & CD & GQD & MD & $\mathrm{AD}$ & $\mathrm{CD}$ \\
\hline TDS & $100 \%$ & $0 \%$ & $0 \%$ & $0 \%$ & $98 \%$ & $0 \%$ & $2 \%$ & $0 \%$ & $99 \%$ & $1 \%$ & $0 \%$ & $0 \%$ \\
\hline TSS & $100 \%$ & $0 \%$ & $15 \%$ & $0 \%$ & $98 \%$ & $0 \%$ & $3 \%$ & $0 \%$ & $99 \%$ & $1 \%$ & $0 \%$ & $0 \%$ \\
\hline EC & $79 \%$ & $21 \%$ & $1 \%$ & $0 \%$ & $77 \%$ & $21 \%$ & $2 \%$ & $0 \%$ & $70 \%$ & $0 \%$ & $30 \%$ & $0 \%$ \\
\hline $\mathrm{pH}$ & $100 \%$ & $0 \%$ & $4 \%$ & $0 \%$ & $98 \%$ & $0 \%$ & $2 \%$ & $0 \%$ & $98 \%$ & $2 \%$ & $0 \%$ & $0 \%$ \\
\hline DO & $100 \%$ & $0 \%$ & $2 \%$ & $0 \%$ & $100 \%$ & $0 \%$ & $0 \%$ & $0 \%$ & $98 \%$ & $2 \%$ & $0 \%$ & $0 \%$ \\
\hline $\mathrm{BOD}_{5}$ & $97 \%$ & $0 \%$ & $8 \%$ & $0 \%$ & $98 \%$ & $0 \%$ & $2 \%$ & $0 \%$ & $92 \%$ & $2 \%$ & $0 \%$ & $6 \%$ \\
\hline COD & $98 \%$ & $0 \%$ & $6 \%$ & $0 \%$ & $99 \%$ & $0 \%$ & $1 \%$ & $0 \%$ & $94 \%$ & $3 \%$ & $0 \%$ & $3 \%$ \\
\hline $\mathrm{NH}_{3}-\mathrm{N}$ & $78 \%$ & $21 \%$ & $6 \%$ & $1 \%$ & $78 \%$ & $21 \%$ & $0 \%$ & $0 \%$ & $67 \%$ & $2 \%$ & $30 \%$ & $1 \%$ \\
\hline $\mathrm{NO}_{3}-\mathrm{N}$ & $98 \%$ & $0 \%$ & $2 \%$ & $2 \%$ & $99 \%$ & $0 \%$ & $0 \%$ & $1 \%$ & $88 \%$ & $0 \%$ & $0 \%$ & $11 \%$ \\
\hline $\mathrm{NO}_{2}$ & $87 \%$ & $11 \%$ & $7 \%$ & $0 \%$ & $88 \%$ & $11 \%$ & $1 \%$ & $0 \%$ & $87 \%$ & $2 \%$ & $11 \%$ & $0 \%$ \\
\hline $\mathrm{PO}_{4}^{3-}$ & $97 \%$ & $0 \%$ & $4 \%$ & $3 \%$ & $97 \%$ & $0 \%$ & $0 \%$ & $3 \%$ & $92 \%$ & $1 \%$ & $0 \%$ & $8 \%$ \\
\hline Fluoride & $76 \%$ & $11 \%$ & $6 \%$ & $3 \%$ & $85 \%$ & $11 \%$ & $0 \%$ & $3 \%$ & $74 \%$ & $3 \%$ & $11 \%$ & $13 \%$ \\
\hline $\mathrm{SO}_{4}$ & $58 \%$ & $42 \%$ & $1 \%$ & $0 \%$ & $59 \%$ & $40 \%$ & $1 \%$ & $0 \%$ & $49 \%$ & $1 \%$ & $49 \%$ & $1 \%$ \\
\hline $\mathrm{H}_{2} \mathrm{~S}$ & $85 \%$ & $10 \%$ & $12 \%$ & $1 \%$ & $85 \%$ & $11 \%$ & $3 \%$ & $1 \%$ & $73 \%$ & $2 \%$ & $11 \%$ & $14 \%$ \\
\hline $\mathrm{Cr}(\mathrm{VI})$ & $67 \%$ & $0 \%$ & $7 \%$ & $6 \%$ & $92 \%$ & $0 \%$ & $1 \%$ & $7 \%$ & $57 \%$ & $2 \%$ & $0 \%$ & $41 \%$ \\
\hline Oil and Grease & $89 \%$ & $11 \%$ & $6 \%$ & $0 \%$ & $86 \%$ & $11 \%$ & $2 \%$ & $1 \%$ & $85 \%$ & $3 \%$ & $11 \%$ & $1 \%$ \\
\hline Detergent & $64 \%$ & $0 \%$ & $11 \%$ & $10 \%$ & $89 \%$ & $0 \%$ & $3 \%$ & $8 \%$ & $54 \%$ & $2 \%$ & $0 \%$ & $44 \%$ \\
\hline E. Coli & $95 \%$ & $0 \%$ & $6 \%$ & $0 \%$ & $98 \%$ & $0 \%$ & $1 \%$ & $1 \%$ & $85 \%$ & $6 \%$ & $0 \%$ & $9 \%$ \\
\hline Total Coliform & $83 \%$ & $0 \%$ & $8 \%$ & $0 \%$ & $98 \%$ & $0 \%$ & $1 \%$ & $0 \%$ & $82 \%$ & $5 \%$ & $0 \%$ & $13 \%$ \\
\hline
\end{tabular}

Note: GQD = Good Quality Data, AD = Abberant Data (data outlier), CD = Censored Data, MVD = Missing Value Data

\subsection{Water Pollution and River Water Quality Target}

There is a difference in the meaning and purpose of quality standards for the water quality conservation and the allotment of multifunctional river water (Saraswati, 2015), and river water quality standards for specific purposes as it is illustrated in Table 3 .

\subsection{River Water Quality Index (WQIs) and River Water Discharge}

The significant water quality variables were selected in the PCA based on the eigenvector value (based on the largest eigenvalue (total data variance) of the largest component, and total component loading $\geq 0.5$ (Hair, et al., 2009). Component loading is a simple correlation between the original variable and the new component or variable, which contains the linear combination of the original variable. Disposing of a very small eigenvector and eigenvalue will not cause any important data loss. The preparation of water quality index has resulted the formula of WQIs for Code River: $0.17 \mathrm{EC}_{\mathrm{t}}+0.16 \mathrm{DO}_{\mathrm{t}}+0.02 \mathrm{COD}_{\mathrm{t}}+0.05 \mathrm{NH}_{3} \mathrm{~N}_{\mathrm{t}}+$ $0.03 \mathrm{TColi}_{\mathrm{t}}$, in Gadjah Wong River: $0.2 \mathrm{EC}_{\mathrm{t}}+0.21 \mathrm{DO}_{\mathrm{t}}+$ $0.15 \mathrm{COD}_{\mathrm{t}}+0.20 \mathrm{NH}_{3} \mathrm{Nt}+0.10 \mathrm{TColi}_{\mathrm{t}}$, and in Winongo River 0,35 EC $\mathrm{E}_{\mathrm{t}}+0,19 \mathrm{DO}_{\mathrm{t}}+0,05 \mathrm{COD}_{\mathrm{t}}+0,04 \mathrm{NH}_{3} \mathrm{~N}_{\mathrm{t}}+0,05$ TColi $_{t}$ where TColi ${ }_{t}$ is Log number (Total Coliform) which was transformed/standardized the WQC. The same process for $\mathrm{EC}_{\mathrm{t}}, \mathrm{DO}_{\mathrm{t}}, \mathrm{COD}_{\mathrm{t}}, \mathrm{NH}_{3} \mathrm{~N}_{\mathrm{t}}$ was the variable result of transformation/ standardization from the concentration of each original variable of water quality measurement results. The general formula of WQIs used the sub-index aggregate "weighted sum index" technique which was similar to INSWQI in Malaysia (Mamun \& Idris, 2008). The significant variables of selected water quality need to be maintained for its reliability and validity towards data of water quality monitoring at all sites which was continuously monitored in the long time, so that the water level information system of the rivers can be well mapped, useful for the priority scale preparation of the pollution control solution.

The water quality index score of the three rivers is shown in Figures 2, 3, 4 on the $\mathrm{x}$-axis and the $\mathrm{y}$-axis which represent the river flow discharge. WQIs index scores are in the range of -1 and +1 which was divided into 2 classes, i.e. the class of good quality water/unpolluted when $0 \leq \mathrm{WQIs} \leq+1$; and class of polluted water, when $0<\mathrm{WQIs} \geq-1$. If the deviation score of WQIs is high (+), then the water quality is good. If the WQIS score is negative, it means the water quality is $\mathrm{bad} /$ polluted. The level of water pollution is based on the deviation of measurable water quality data towards water quality conservation (WQC) standards in Table 1 column (4) with equations (1) to (4). 
Table 3. Differences in river water targets for specific and general water use

\begin{tabular}{|c|c|c|}
\hline Variables Review & Specific Usage & General Use/Multifunction \\
\hline Utilization of river water & $\begin{array}{l}\text { Raw Water of Drinking water } \\
\text { (example) }\end{array}$ & $\begin{array}{l}\text { Multifunction/natural background/water quality } \\
\text { conservation, for the habitat of aquatic biota, raw water for } \\
\text { drinking water, agriculture, fishery and other }\end{array}$ \\
\hline \multirow{3}{*}{$\begin{array}{l}\text { Quality standards target } \\
\text { of water quality } \\
\text { Significant Water quality } \\
\text { parameter indicators }\end{array}$} & $\begin{array}{l}\text { Human health criteria. The } \\
\text { universal standards (WHO): }\end{array}$ & $\begin{array}{l}\text { Criteria considering climate, hydrogenobiochemical and } \\
\text { biodiversity in each aquatic ecoregion. Local standards. }\end{array}$ \\
\hline & Bacteriology and mineral water & $\begin{array}{l}\text { Parameters of physical, chemical, bacteriological, } \\
\text { ecotoxicity to biota }\end{array}$ \\
\hline & $\begin{array}{l}\text { Drinking water as it is not a } \\
\text { habitat for aquatic biota }\end{array}$ & River waters and others as habitats of aquatic biota \\
\hline $\begin{array}{l}\text { Location for water } \\
\text { quality monitoring }\end{array}$ & $\begin{array}{l}\text { Certain, e.g. in raw water } \\
\text { intake, installation of drinking } \\
\text { water purification }\end{array}$ & $\begin{array}{l}\text { In many locations, periodically, over long periods (spatial, } \\
\text { time series) }\end{array}$ \\
\hline $\begin{array}{l}\text { Agency responsible for } \\
\text { the task }\end{array}$ & $\begin{array}{l}\text { Regional Water Company, } \\
\text { Ministry of Health }\end{array}$ & $\begin{array}{l}\text { Water Resources Manager of the Ministry of Public Works } \\
\text { and Ministry of Environment. }\end{array}$ \\
\hline
\end{tabular}

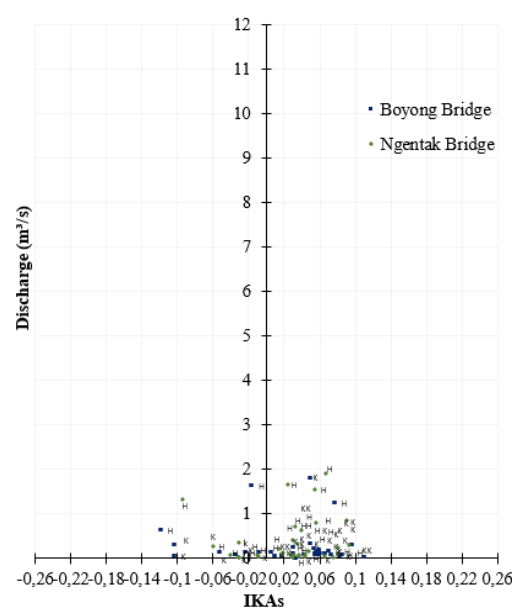

(a) Code River

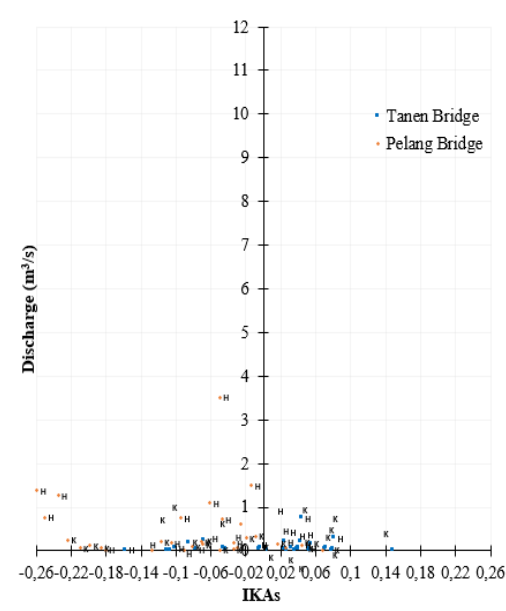

(b) Gadjah Wong River

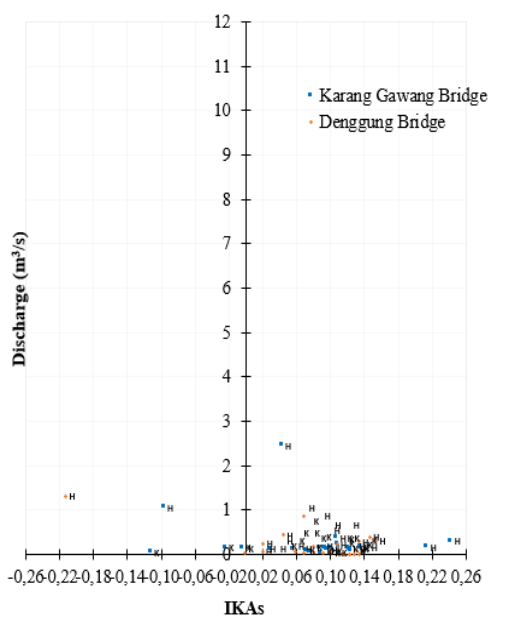

(c) Winongo River

Figure 2. The distribution of WQIs and discharge points at the monitoring site of the upstream area of the rivers.

Table 4. Percentage of water quality status in the upstream area of Code, Gadjah Wong and Winongo Rivers

\begin{tabular}{lllll}
\hline \multirow{2}{*}{ No. } & \multirow{2}{*}{ River } & Location & \multicolumn{2}{l}{ Water Quality Status } \\
\cline { 4 - 5 } 1 & \multirow{2}{*}{ Code River } & Boyong Bridge & Good & Polluted \\
& & Ngentak Bridge & $76 \%$ & $24 \%$ \\
2 & \multirow{2}{*}{ Gadjah Wong River } & Tanen Bridge & $76 \%$ & $24 \%$ \\
& & Pelang Bridge & $71 \%$ & $29 \%$ \\
3 & \multirow{2}{*}{ Winongo River } & Karang Gayam Bridge & $13 \%$ & $88 \%$ \\
& & Denggung Bridge & $86 \%$ & $14 \%$ \\
\hline
\end{tabular}

Distribution of WQIs scores and river discharge at monitored locations and river upstream in Code, Gadjah Wong and Winongo River are presented in Figure 2.

The Winongo River was frequently observed as uncontaminated (WQIs $\geqq 0$ ) than Code and Gadjah Wong Rivers. The increase in pollution cases was commonly happened during the dry season and moreover in the year 2015. Most water pollution cases were shown in the Gadjah Wong River, which was measured in Pelang Bridge, as it is presented in Table 4 and Figure 2 (b). In the upstream area, river water flow was generally recorded at 0.014 to $<2$ $\mathrm{m}^{3} / \mathrm{sec}$. Upstream water discharge at Code River is higher than the other rivers. High river water discharge has occurred during the rainy season and measured at its highest value in February 2011, with relatively good water quality in the Winongo and Code River. Meanwhile, in the Gadjah Wong River, the water was polluted.

Distribution of WQIs scores and river water discharge at the monitoring points of Code, Gadjah Wong, and Winongo Rivers, are presented in Figure 3. 
The high percentage of polluted water occurred in the midstream area of the three rivers, with the highest pollution water in the Gadjah Wong River both during the dry or rainy season. The better water quality was shown in the Winongo River (Table 5). The flow of river water in the midstream area of the three rivers was generally at $0.1-4 \mathrm{~m}^{3} / \mathrm{s}$, higher than at the upstream area with various water status. High river water discharges were generally measured in February and April, with its peak in February 2011, as the trend showed good water quality (WQIs $\geqslant 0$ ). In February 2011, at the Code and Winongo rivers, the WQIs score $\geqslant 0$ (comply with the quality standard of river water) with discharge value of $11.4 \mathrm{~m}^{3} / \mathrm{s}$

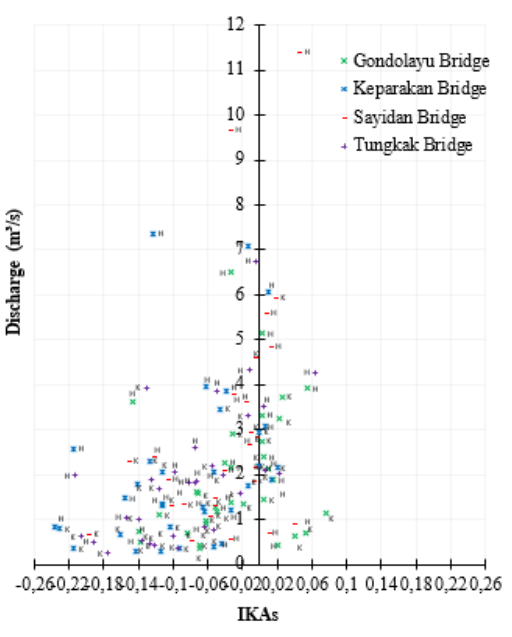

(a) Code River

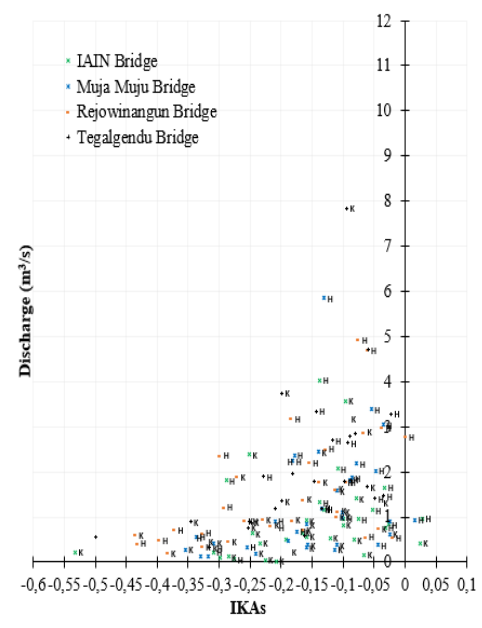

(b) Gadjah Wong River

Figure 3. The WQI dynamics and discharge at monitored locations in the midstream area of the river

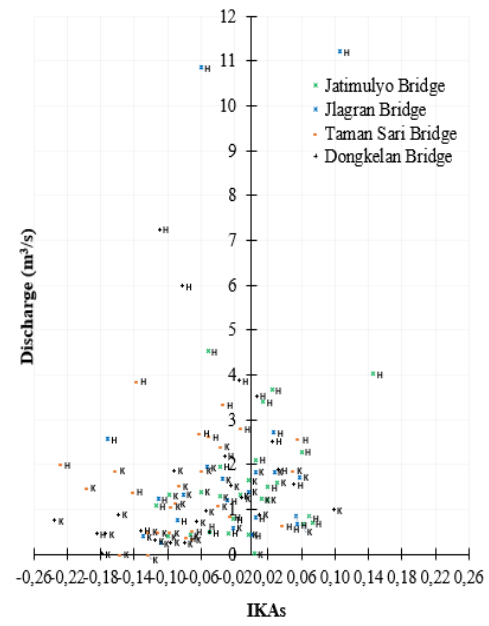

(c) Winongo River

Table 5. Percentage of water quality status in the midstream area of Code, Gadjah Wong and Winongo River

\begin{tabular}{|c|c|c|c|c|}
\hline \multirow{2}{*}{ No. } & \multirow{2}{*}{ River } & \multirow{2}{*}{ Location } & \multicolumn{2}{|c|}{ Water Quality Status } \\
\hline & & & Good & Polluted \\
\hline \multirow[t]{4}{*}{1} & Code River & Gondolayu Bridge & $42 \%$ & $58 \%$ \\
\hline & & Keparakan Bridge & $12 \%$ & $88 \%$ \\
\hline & & Sayidan Bridge & $22 \%$ & $78 \%$ \\
\hline & & Tungkak Bridge & $13 \%$ & $87 \%$ \\
\hline \multirow[t]{4}{*}{2} & Gadjah Wong River & IAIN Bridge & $6 \%$ & $94 \%$ \\
\hline & & Muja Muju Bridge & $3 \%$ & $97 \%$ \\
\hline & & Rejowinangun Bridge & $3 \%$ & $97 \%$ \\
\hline & & Tegalgendu Bridge & $0 \%$ & $100 \%$ \\
\hline \multirow[t]{4}{*}{3} & Winongo River & Jatimulyo Bridge & $50 \%$ & $50 \%$ \\
\hline & & Jlagran Bridge & $43 \%$ & $57 \%$ \\
\hline & & Tamansari Bridge & $11 \%$ & $89 \%$ \\
\hline & & Dongkelan Bridge & $23 \%$ & $77 \%$ \\
\hline
\end{tabular}

Distribution of WQIs scores and river water discharge on the monitoring points at a downstream area of Code, Gadjah Wong and Winongo Rivers are presented in Figure 4. The percentage of water quality data with a status of polluted and unpolluted water at the downstream area is presented in detail in Table 6, Figure 4 (a), and Table 6, where the data recorded its highest value at Code River $(18 \%-24 \%)$ with good water quality (WQIs score $\geqslant 0$ ) compared to the downstream area of the Winongo River (8\%). The condition generally occurs when the river water discharge was $0.02 \mathrm{~m} 3 / \mathrm{sec}$ to $<4 \mathrm{~m} 3 / \mathrm{s}$. In the downstream area of Gadjah Wong River, almost all water quality data were recorded as polluted.

A very high river discharge was recorded in the downstream area of Code, Gadjah Wong, and Winongo Rivers at the same time on February, and the highest

value was recorded in 2011. At the Code and Winongo Rivers, the increased discharge can make a better 
water quality index (Figure 4 (a) and (c)), but it was recorded as the bad value at the Gadjah Wong River. The distribution of WQIs scores and discharge at monitoring locations in the river downstream area is presented in Figure 4.

Fluctuations of discharge value at each monitoring site are high because of the change in land use and hydrology of both watersheds. The field observations indicated that there has been a change from agricultural functions (gardens, forests, field) into the settlement at the upstream area of the river. In the midstream and downstream area, the population density and industrial activity are increasing, which caused more liquid and solid waste. River flow accumulation occurred in the downstream area and the ecosystem conditions have not been able to cope with the high pollution load.

Table 6. Percentage of water quality status at downstream area of Code, Gadjah Wong and Winongo Rivers

\begin{tabular}{|c|c|c|c|c|}
\hline \multirow{2}{*}{ No. } & \multirow{2}{*}{ River } & \multirow{2}{*}{ Location } & \multicolumn{2}{|c|}{ Water Quality Status } \\
\hline & & & Good & Polluted \\
\hline \multirow[t]{2}{*}{1} & Code River & Abang Bridge & $18 \%$ & $82 \%$ \\
\hline & & Pacar Bridge & $24 \%$ & $76 \%$ \\
\hline \multirow[t]{2}{*}{2} & Gadjah Wong River & Wirokerten Bridge & $0 \%$ & $100 \%$ \\
\hline & & Wonokromo Bridge & $0 \%$ & $100 \%$ \\
\hline \multirow[t]{2}{*}{3} & Winongo River & Bakulan Bridge & $0 \%$ & $100 \%$ \\
\hline & & Gading Bridge & $8 \%$ & $92 \%$ \\
\hline
\end{tabular}

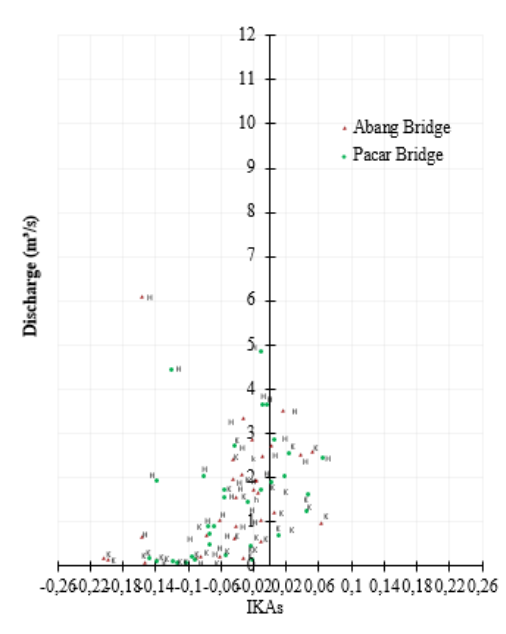

(a) Code River

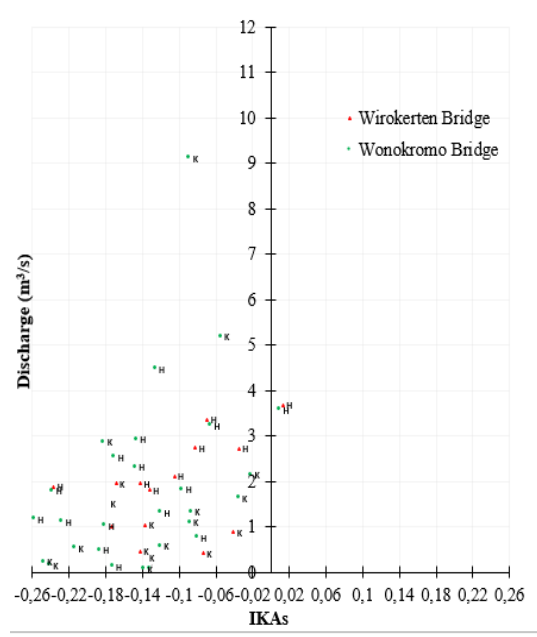

(b) Gadjah Wong River

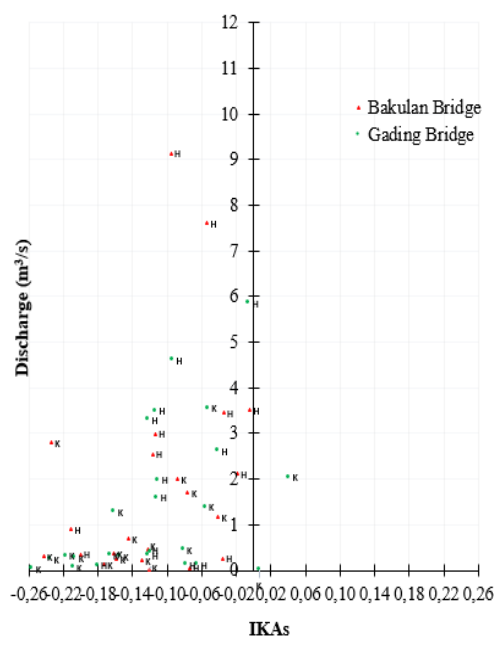

(c) Winongo River

Figure 4. Dynamics of WQI and discharge at monitored locations of the downstream area of the river.

\section{CONCLUSIONS}

Pollution threats have emerged in the upstream area. Cases of river pollution have increased at the midstream area of the three rivers for a long time ago. The Gadjah Wong River is the most polluted river, compared to Code and Winongo Rivers. While the Winongo River on the west side of Yogyakarta city is the best in its water quality. Field observations found the changes from agricultural functions (gardens, forests, moorings) into settlements area. The rain caused high river water discharge, and the water quality status tends to be good based on the quality standard. However, the high river water discharge in February 2011 and 2015 caused the polluted river water quality. The wastewater and waste handling system so far has been considered ineffective to control water pollution in the rivers. It is necessary to consider the effort to control river water pollution by flowing the polluted river water into the retention basin or in the river bank during the dry season, as a means of water purifying system, and then flow it back to the river.

\section{ACKNOWLEDGMENTS}

The authors acknowledge Prof. Bambang Agus Kironoto and Prof. Sunjoto for the supervision, also Civil and Environmental Engineering Department, Universitas Gadjah Mada, and Directorate General of Higher Education, Ministry of Education and Culture for the financial support during the research at Gadjah 
Wong stream. The author would like to express her sincere gratitude to the Environmental Agency of Yogyakarta for the research data.

\section{REFERENCES}

Abbasi, S. A. \& Sarkar, C., 2006. Qualidex-A New Software for Generating Water Quality Indice. Environmental Monitoring and Assessment, Volume 119, pp. 201-231.

Badan Lingkungan Hidup (BLH) DIY, 2015. Water Quality Monitoring and Data Analysis in Yogya Special Province. Yogyakarta: Badan Lingkungan Hidup DIY.

Berthouex, P. M. \& Brown, L. C., 2002. Statistic for Environmental Engineers. 2nd ed. New York: Lewis Publishers.

Dudgeon, D., 1999. Tropical Asian Streams: Zoobenthos, Ecology and Conservation. Hongkong: Hongkong University Press.

Hair, J. F., Black, W. C., Babin, B. J. \& Anderson, R. E., 2009. Multivariate Data Analysis. 7th ed. UK: Pearson Prentice Hall.

Kannel, P. R., 2007. Application of Water Quality Indices and Dissolved Oxygen as Indicators for River Water Classification and Urban Impact Assessment. Journal Environmental Monitoring Assessment, Volume 132, pp. 93-110.

Karr, J. R., 1991. Biological Integrity: A LongNeglected Aspect of Water Resources Management. Ecological Applications, 1(1), pp. 66-84.
Liou, S. M., Lo, S. L. \& Wang, S. H., 2004. A Generalized Water Quality Index for Taiwan. Environmental Monitoring and Assessment, Volume 96, pp. 35-52.

Lumb, A., Halliwell, D. \& Sharma, T., 2006. Application of CCME Water Quality Index to Monitor Water Quality: A Case of the Mackenzie River Basin Canada. Environment Monitoring and Assessment, Volume 113, pp. 411-429.

Mamun, A. A. \& Idris, A., 2008. Revised Water Quality Indices for The Protection of Rivers in Malaysia. Alexandria, Egypt, pp. 1687-1698.

Putranda, J. \& Saraswati, S. P., 2016. Identification of Water Quality Parameters with Two Transformation /Standardization Methods on Principal Component Analysis and Scilab Software. Journal of Civil Engineering Forum, 2(3), pp. 109-120.

Saraswati, S. P., 2015. Development of New Methods to Determine the Health Status of River Based on ecohydraulics Approach, Yogyakarta: Universitas Gadjah Mada.

Saraswati, S. P., 2017. Comparative Analysis of Water Quality Indices. Kuala Lumpur, International Association for Hydro-Environment Engineering and Research, pp. 260-269.

Thomann , R. V. \& Mueller , J. A., 1987. Principles of Surface Water Quality Modelling and Control. New York: Harper and Row Publishers. 
[This page is intentionally left blank] 